\title{
Egészpályás letámadás a kövérség ellen - Komplex beavatkozásokkal az elhízás visszaszorítására
}

\author{
Fullback tactics against obesity - Complex interventions to \\ control obesity
}

\author{
Szerző: $\quad$ Vitrai József ${ }^{a} \bowtie$, Bakacs Márta ${ }^{b}$ \\ a: Emberi Erőforrások Minisztériuma, b: Országos Gyógyszerészeti és \\ Élelmezés-egészségügyi Intézet
}

Beküldve: 2017. 11. 16.

doi: $10.24365 /$ ef.v58i4.211

\begin{abstract}
Összefoglaló: A túlsúly és az elhízás komoly terhet jelent az egyének, a családok és az egész társadalom számára. A magyarországi elhízás visszaszorítására komplex kormányzati intézkedéscsomag összeállítása indokolt, hasonlóan a dohányzás elleni küzdelemben hatásosnak bizonyult csomaghoz. Ennek fő elemei: egyrészt az elhízás megelőzése, a lefogyásra vonatkozó tudás bővítése, másrészt a viselkedésváltozás motiválása, harmadrészt pedig a megelőzést és a lefogyást támogató környezet kialakítása. A három cél egyidejű teljesítése korszerű elméletekre és nemzetközi tapasztalatokra alapozott, több szektorra kiterjedő, komplex program megvalósítását teszi szükségessé.
\end{abstract}

Kulcsszavak: elhízás; komplex beavatkozás; egészségmagatartás, környezet

Summary: Overweight and obesity put serious burden on individuals, on families, and on the whole society. To control the obesity in Hungary, it is suggested to assemble complex, effective governmental interventions similar to those against the smoking. Interventions aim, firstly to improve the knowledge on prevention of obesity and on losing weight, secondly to motivate people to change their behavior, and thirdly to build environment for supporting the lifestyle leading to prevention and losing weight. To meet this triple goals at a time, it is necessary to carry out complex program by multiple sectors using current theories and experiences.

Keywords: obesity; complex intervention; health behavior; environment

\section{BEVEZETÉS}

Írásunkban amellett érvelünk, hogy új taktika szükséges a hazai „elhízásjárvány” legyőzéséhez. Az elhízás visszaszorítása csakis sokszereplős, egyidejûleg sok szinten, sokféle beavatkozással valósítható meg.
A túlsúly és az elhízás' gyakorisága világszerte növekszik. $^{1}$ Kutatások igazolják, hogy a magas testtömegindex számos és egyre többeket érintő krónikus betegség okozója, mint a szív- és érrendszeri betegségek, a cukorbetegség, a krónikus vesebetegségek, többféle daganatos és mozgásszervi betegség.

\footnotetext{
¡Túlsúlyosnak azok minősülnek, akiknek a testtömegindexe nagyobb, mint 25; elhízottnak számít, akinél ez az érték 30 vagy annál nagyobb. Testtömegindex: kilogrammban mért testsúly osztva a méterben megadott testmagasság négyzetével; angolul body-mass index, BMI.
} 
Az elhízás az egészségügyi kiadások 2-8 százalékáért és a halálozások 10-13 százalékáért felelős az Európai Régióban. "Hazánkban a felnőtt lakosság 54 százaléka túlsúlyosnak vagy elhízottnak számított a 2014-es Európai Lakossági Egészségfelmérés során bemondott testsúly és testmagasság alapján. ${ }^{2}$ A felmérés kisebb mintáján megvalósított Országos Táplálkozás és Tápláltsági Állapot Vizsgálatban, a mért adatokra alapozott számítások szerint a felnőttek 62\%-a volt túlsúlyos vagy elhízott. ${ }^{3}$ A fejlett országok ranglistáján Magyarország az elhízottak 30\%-os arányával az USA, Mexikó és Új-Zéland után a negyedik leginkább érintett. ${ }^{4, i i i}$

A 11-13-15 éves magyar iskolás fiúk körében a túlsúly és elhízás együttes aránya (31-28-24 százalék) meghaladja a más európai országokban mért értéket. ${ }^{5} \mathrm{Az}$ OECD legfrissebb adatai alapján Magyarországnál $(25,5 \%)$ az európai tagországok közül csak Portugáliában (28,5\%), Görögországban $(29,4 \%)$ és Spanyolországban (31,9\%) volt gyakoribb a mért értékek alapján számított gyermekkori elhízás. ${ }^{4}$ Norvégiában volt a legkevesebb gyermek (14,5\%) túlsúlyos vagy elhízott, ami 11 százalékponttal alacsonyabb a magyar értéknél.
A magyarországi elhízás visszaszorítására egy komplex kormányzati intézkedéscsomag összeállítása indokolt, hasonlóan a dohányzás elleni küzdelemben hatásosnak bizonyult csomaghoz, egyrészt az elhízás megelőzésére és a lefogyásra vonatkozó tudás bővítésére, másrészt a viselkedésváltozás motiválására, harmadrészt a megelőzéshez és a lefogyáshoz vezető életmódot támogató környezet kialakítására. A három cél egyidejű teljesítése korszerű elméletekre és nemzetközi tapasztalatokra alapozott, több szektorra kiterjedő, komplex program megvalósítását teszi szükségessé.

\section{BEAVATKOZÁSI TERÜLETEK}

A programmal kapcsolatos komplexitás követelményét számos közlemény teszi nyilvánvalóvá, hiszen az egészséget különböző szinteken, sokféle tényező egyidejúleg befolyásolja. A társadalmi-gazdasági, kulturális és környezeti hatások kétséget kizáróan szerepet játszanak az egyének, sőt a közösségek magatartásában, illetve azt meghatározó biológiai és mentális jellegzetességek alakulásában.

1. ábra: Egészségbarát viselkedést befolyásoló hatásháló

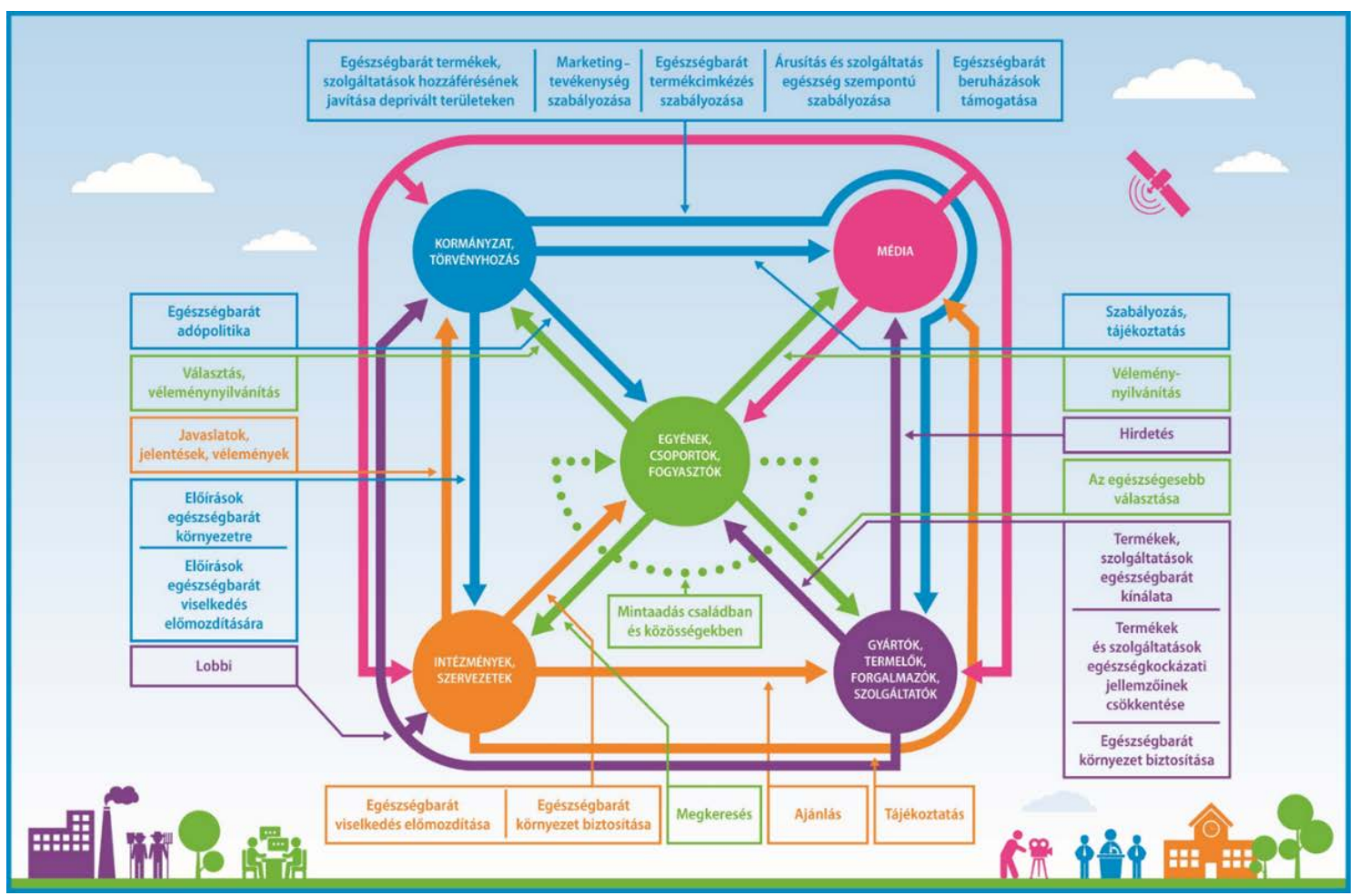

\footnotetext{
ii WHO European Region; http://www.euro.who.int/en/health-topics/noncommunicable-diseases/obesity/obesity (Elérve: 2017. 11. 11.)

iii Obesity Update 2017, OECD; http://www.oecd.org/health/obesity-update.htm (Elérve: 2017. 11. 11.)
} 
Mivel az elhízás hátterében sokféle egyéni, közösségi és környezeti tényező komplex rendszere áll, az elhízás visszaszorításában siker csakis több szinten, sok szereplő többféle, térben és időben összehangolt tevékenységével érhető $\mathrm{el}^{6}$, amint azt a The Lancet elhízással kapcsolatos cikksorozatából átvett 1. ábra illusztrálja. ${ }^{78}$

Az elhízás visszaszorítását célzó, javasolt komplex program három említett célkitǔzése a viselkedésváltoztatás ma leginkább elfogadott modellje (COM-B) alapján került kijelölésre. ${ }^{9} \mathrm{~A}$ viselkedéspszichológia közelmúltban integrált elmélete ugyanis kimondja, hogy az egyének és a közösségek viselkedését (1) a tudás, azaz a fizikai és mentális képességek, (2) a motivációk és szokások, valamint (3) a társas és fizikai környezet együttesen határozzák meg. Az elhízás megelőzéséhez és a fogyáshoz vezető életmód magyarországi elterjedéséhez ebből következően mindhárom célterületen egyidejúleg kell változást elérni. A következőkben sorra vesszük, hogy az adott cél eléréséhez milyen beavatkozások jöhetnének számításba

\section{Tudásbővítés}

Az elhízáshoz vezető, illetve a lefogyást támogató egészségmagatartás okainak és következményeinek megértetésére, a problémához kapcsolódó ismeretek fejlesztésére elsősorban széles körü, célcsoportspecifikus kommunikációs kampányok jöhetnek szóba.

Célcsoportként praktikus külön kezelni a gyermekeket, fiatalokat, mivel ők egyfelől könnyen elérhetők a köznevelési intézményekben, másfelől a náluk elért változás egész életükre, így idővel az egész társadalomra kihat. További előnyt jelent esetükben, hogy az őket egészséges életmódra nevelő pedagógusok képzése-továbbképzése koncentráltan, a felsőfokú intézményekben megoldható. Az elhízás megelőzéséhez vezető táplálkozási, testmozgási ismeretek fejlesztése, a szükséges készségek kialakítása az óvodában és az iskolában részben kötött foglalkozások (előadások, filmvetítések, tanórák), rész- ben kötetlen játékok, versenyek segítségével történhet. Erre jó példa a 2007 tavaszán, az akkori Országos Élelmezés- és Táplálkozástudományi Intézet által, nemzetközi programok mintájára kidolgozott HAPPY (,Hungarian Aqua Promoting Program in the Young" - "Magyarországi vízfogyasztást népszerüsítő program a fiatalok körében") modellprogram, melyben a pedagógusok számára készített oktatási segédanyagok, óravázlatok mellett számos, tanórán kívüli kreatív, játékos programelemmel népszerüsítik a vízfogyasztást.

Újabban egyre több honlapiv , okostelefonra fejlesztett program kínál a gyermekek számára vonzó, játékos lehetőséget az egészséges magatartáshoz szükséges ismeretek megszerzéséhez. Ilyen kommunikációs formák alkalmazása - egyelőre meggyőző bizonyítékok híján ${ }^{10,11,12,13}$ - feltehetően növelheti a gyermekeket és a fiatalokat célzó kommunikáció eredményességét.

A középkorúak felé irányuló kommunikáción belül érdemes az életkoron túl, más szociális-demográfiai jellegzetességek alapján alcsoportokat képezni. Közülük elsősorban az alacsony iskolázottságúak jöhetnek számításba, hiszen az elhízás kockázata főként ebben a csoportban magas. Esetükben leginkább a hagyományos kommunikációs csatornák lehetnek hatásosak, mint az újságok, a tv és a rádió. Az egészséges táplálkozással kapcsolatos ismereteik növelésére a napjainkban közkedvelt főzőmúsorok, főzőversenyek, vetélkedők lehetnek eredményesek. Specifikus kommunikációval kellene megszólítani a gyermeket tervező és a gyermeket nevelő szülőket, mert az ő magatartásuk meghatározó a családban élők életmódját illetően. Az őket célzó kommunikációnak főként az elhízás életminőséget érintő következményeire (pl. érintettekkel készített interjúk a mozgásszervi elváltozásokról), továbbá a lefogyáshoz vezető különféle lehetőségek (pl. elhízottaknak ajánlott aquafitness ${ }^{v i}$ ) bemutatására kellene fókuszálnia.

Az életkor mint célcsoportképző sajátosság az idősebbeknél is felmerül. Az ő esetükben a speciális kommunikációt az elhízás következményeként várhatóan fellépő magas egészségügyi ellátási költség

\footnotetext{
iv http://www.okosdoboz.hu/, http://www.tinivagyok.hu/temak/tinikonyha, https://www.learninggamesforkids.com/health_games.html, https://www.healthyeating.org/Healthy-Kids/Kids-Games-Activities, http://pbskids.org/games/healthy-habits/ (Elérve: 2017. 11. 12.) v https://play.google.com/store/search?q=eg\%C3\%A9szs\%C3\%A9g\%20gyerek\&c=apps, https://www.bestappsforkids.com/category/kids-apps-bycategory/health-apps-for-kids/, https://www.commonsensemedia.org/lists/best-health-apps-and-games-for-kids (Elérve: 2017. 11. 12.) vi http://www.webbeteg.hu/cikkek/sport egeszseg/9767/aquafitness-edzes-es-torna-a-vizben (Elérve: 2017. 11. 12.)
} 
magyarázza. E célcsoportban a testmozgás előmozdítása különösen indokolt, hiszen az nemcsak az elhízás megelőzését és a fogyás elősegítését szolgálja, hanem az esetükben gyakran végzetes következményekkel járó elesés megelőzését is. Ebben a korban a mozgás pszichés hatása sem elhanyagolható, mivel a mozgás esetükben örömérzettel jár, segít a mozgékonyság megőrzésében, véd az egyhangúság és - csoportos formában végezve - az elszigetelődés ellen is. Alkalmas kommunikációs forma lehet számukra a hagyományos média, valamint tájékoztató anyagok kihelyezése a gyógyszertárakban.

\section{Motiváció}

Az elhízás visszaszorítását támogató kommunikáció során törekedni kellene arra, hogy a tudásnövelés mellett motiválja is egészséges táplálkozásra és testmozgásra az adott célcsoportot. Erre jó példa lehet a dohányzás ártalmait sokkolóan bemutató „Tanácsok korábban dohányzóktól” kommunikációs kampány bizonyított hatásossága. ${ }^{14}$ Ahogy ebben a kampányban is, az érintettek magukról szóló beszámolói erősen motiválóak, mert hitelessé és ezzel meggyőzővé teszik a kommunikációs üzeneteket. Számos fejlett országban található jó példa az elhízás megelőzését célzó kommunikációs kampányra.iii A Spanyolországban, Németországban, Észtországban, Chilében, Mexikóban és Új-Zélandon is megvalósított "Naponta 5" kampány mellett, Dániában „Naponta 6”, Nyugat-Ausztráliában „Naponta 2+5”, az Egyesült Államokban „Gyümölcs és zöldség - a több számít!" szlogennel mozgósítják a lakosságot a több gyümölcs- és zöldségfogyasztásra. A Magyar Zöldség-Gyümölcs Szakmaközi Szervezet 1997-ben indította el az amerikai „Naponta 5” magyarországi adaptációját, a „Naponta $3 \times 3$ ” programot. vii Honlapjukon a gyümölcs és zöldségfogyasztást támogató ismeretek mellett, mozgósító eseményekről szóló hírek is találhatók.

Motiválásra a kommunikációs szakemberek különböző csatornákat, formákat alkalmaznak világszerte. Franciaországban 2001 óta az egészséges étkezésre és mozgásra buzdító „Egyél, mozogj!” kampány a hagyományos médián kívül videókat és lakcímekre eljuttatott szóróanyagokat valamint e célra múködtetett honlapot használ a lakosság elérésére. Az ausztrál „Élj könnyebben!” kampány ingyenes receptekkel, az egyéni étkezés és testmozgás megtervezését szolgáló naplókkal motiválja egészséges táplálkozásra és több mozgásra a lakosságot 2012 óta. Írországban a 2013-ban indított „Figyeljünk a gyermekelhízásra!” kampány keretében gyakorlati segítséget, étkezési tervezőnaplót, ételkészítési ötleteket adnak a szülőknek az elhízáshoz vezető szokások megváltoztatásához. A magas energiatartalmú ételek fogyasztásának visszaszorítására 2013-ban Mexikóban indított átfogó médiakampány a tv-ben, az interneten, a rádióban, a mozifilmek előtt, a plakátokon és a tömegközlekedési eszközökön megjelenő üzenetekből állt.

Főképpen a fiatal felnőtteket célozzák a közösségi média alkalmazásával megvalósított kampányok. Hollandiában az egészséges élelmiszerek viii választásának bátorítására honlapon, mobiltelefon-applikáción és online eszközökön kínálnak egészséges étkezéshez recepteket, ötleteket. Ezek segítséget nyújtanak a felhasználóknak a viselkedésük lépésről lépésre történő megváltoztatásához, egyéni igényekhez igazodó tanácsokkal, videókkal. A chilei kormány 2013-ban indított, „Válaszd az egészséges életmódot!" kampányában - szociális marketingelemként - kínált kalóriabevitel-számító internetes alkalmazást. Hasonlóan, Észtországban online kampányt indítottak a magas só- és cukortartalmú élelmiszerek fogyasztásának visszaszorítására. A kampány honlapján lehetőség volt a fogyasztani kívánt ételek só- és cukortartalmának meghatározására, továbbá a forgalomban lévő termékek tápanyagösszetételének ellenőrzésére. Svájcban fizikaiaktivitás-versenyre hívták a kantonokat 2015 nyarán, melynek során a résztvevők mobilapplikációval vagy egy honlapon online nevezhettek. Az egy hétig tartó versenyben 88 ezren öszszesen több mint egymillió kilométert gyalogoltak. 2014-ben a só-, cukor- és telítettzsírsav-fogyasztás csökkentését célzó, angol "Okos váltás" kampányban az ételkészítési ötletek, receptek mellett egy "Legyél étel-okos!" mobilapplikációt lehetett letölteni a kampány honlapjáról, ami a csomagolás vonalkódja alapján

\footnotetext{
vii www.3x3.hu; (Elérve: 2017. 11. 12.)

viii Olyan élelmiszerek, amelyeknek fogyasztása az egészség szempontjából előnyös
} 
kijelezte a termék só-, cukor- és zsírtartalmát.

$\mathrm{Az}$ egészséges táplálkozásra és a testmozgásra motiválást szolgálhatják egyének vagy közösségek számára rendezett, médiában követett, országos és helyi vetélkedők, versenyek vagy támogatásra, díjakra kiírt pályázatok. Ezek a motivációs eszközök hozzájárulnak a közösség normáinak, értékeinek, és ezáltal az egyénekkel szemben megnyilvánuló elvárásoknak a kialakulásához, mobilizálva ezzel a közösség tagjait az elvárt viselkedés irányába. ${ }^{15}$ Ezt támasztják alá például az Országos Egészségfejlesztési Intézet és az Egészségesebb Munkahelyekért egyesület „Közösen-könnyebben” életmódprogramjánakix vagy az „Egészségedre - Mókuskerék helyett” munkahelyi közösségek számára kiírt pályázatának ${ }^{x}$ tapasztalatai is.

Itt kell említést tenni az egészségkockázatot jelentő élelmiszerek reklámozásának szabályozásáról, azaz a motiválás korlátozásáról. A fejlett országok között elterjedt gyakorlat a gyermekeket és fiatal felnőtteket célzó, étel- és italreklámok korlátozása. Például Spanyolországban, Izlandon, Chilében és Mexikóban tilos ételt és italt reklámozni a tv-ben és a rádióban azokban az órákban, amikor a nézők-hallgatók zömét gyerekek teszik ki. Ugyancsak tiltottak az ilyen reklámok a tömegközlekedési eszközökön például Ausztráliában, Norvégiában a közterületeken, ahol a gyártók és forgalmazók önkéntes korlátozást vállaltak a 13 évnél fiatalabbak védelmében 2013-ban. A korlátozás kiterjed a 18:30 előtt vetített reklámfilmekre, versenyekre, interaktív játékokra. A magas só-, zsír- és cukortartalmú termékek reklámjára Dániában már 2008 óta érvényben van hasonló, a televíziómúsorokra, a nyomtatott sajtóra és az internetre vonatkozó megállapodás. A 14 év alattiaknak szánt hirdetéseket tiltja egy chilei törvény akkor, ha egy megadott határértéket meghalad a reklámozott termékben a kockázatot

jelentő tápanyag. Lettországban és Litvániában tilos energiaitalt hirdetni 18 évesnél fiatalabbaknak szánt tévéprogramok előtt, alatt, után, továbbá oktatási intézményben és sportlétesítményekben. Az szlovén ipar önként vállalta a cukros üdítők reklámozásának 12 év alatti gyermekekre vonatkozó korlátozását iskolában, újságokban. Kutatások azt igazolják, hogy az említett korlátozások pozitív hatással járnak mind a tápanyagenergia-bevitel, mind az ételminőség, és valamennyire a reklámnak való kitettség területén. A tapasztalatok szerint azonban az önként vállalt korlátozások - a sajátos ipari érdekeknek megfelelően - a jogszabályokkal szemben kevesebb eredménnyel járnak. ${ }^{16,17}$

\section{Környezet}

A társas környezet fontossága az elhízás megelőzéséhez és a lefogyáshoz vezető életmód kialakításában az előzőekben, a motivációknál már említésre került. Ugyanis a társas környezet, azaz a család, a barátok, a munkatársak, a látókörünkbe került véleményvezérek (mai szóhasználattal a celebek) véleménye, elvárásai egyértelmúen meghatározzák motivációinkat, és ezáltal viselkedésünket. A továbbiakban az épített valamint az információs környezetnek az elhízás visszaszorításában szerepet játszó jelentős funkciójáról lesz szó.

Az épített környezetnek az egészséges táplálkozásban és testmozgásban játszott szerepe már évek óta a népegészségügyi szakirodalom fókuszában áll. ${ }^{18}$ A nemzetközi tapasztalatok felhasználásával, különböző szakterületek együttmúködésének eredményeként 2016-ban Magyarországon is elérhetővé vált egy egészséges életmódot támogató várostervezésre vonatkozó ajánlás. ${ }^{19} \mathrm{Az}$ ajánlások egy részének megvalósítása a gyaloglás és a kerékpározás elterjesztését szolgálná (pl. sétálásra invitáló környezetben jármúvektől jól elkülönített járdák kialakítása, a liftek helyett a lépcsőhasználatot támogató épülettervezés vagy biciklitároló és öltöző épületen belüli biztosítása a munkahelyeken), más, itt releváns része az egészséges táplálkozást támogatná (pl. kisebb termelői piacok helyének kialakítása). Az elhízás visszaszorítása érdekében jogszabály írhatná elő az ilyen ajánlásoknak a városfejlesztés és egyéb építészeti tevékenységek során való figyelembevételét. Ezáltal olyan épített köztereket, épületeket lehetne kialakítani, melyekben az ott élők gyakrabban választanának egészséges élelmiszereket, ételeket, és többet mozognának.

Az egészséges táplálkozás előmozdítása érdekében a jelenleginél sokkal jobban kellene informálni a fogyasztókat. Ehhez a forgalmazókat, vendéglátókat kötelezni kellene arra, hogy az élelmiszerek és az

\footnotetext{
ix http://regi.oefi.hu/lakossagi.htm (Elérve: 2017.10.17.)

${ }^{x}$ http://mokuskerekhelyett.blog.hu/ (Elérve: 2017.10.17.)
} 
ételek egészségkockázatot jelentő tulajdonságait könnyen érthető formában tüntessék fel a csomagoláson vagy az éttermi menüben. Néhány államban már kötelező feltüntetni az ételek energiatartalmát az étlapon (pl. 2017 májusától USA-ban az étteremláncokra nézve, néhány ausztrál államban 2016 óta, a kanadai Ontarióban 2017-től kezdődően). A menüben az ételek mellett a tápanyagösszetételnek is szerepelnie kell, írja elő néhány önkormányzat például New York Cityben és Philadelphiában, de hasonló szabályozás van érvényben Kalifornia és Vermont államban is. Egy ausztrál esettanulmány szerint az étlapon szereplő tápanyaginformációk miatt a fogyasztók 120 kcal-val kisebb energiatartalmú ételeket választottak. Mások csak kismértékű csökkenést tudtak kimutatni az energiabevitelben, bár a megkérdezettek 28\%-a állította, hogy választásukat befolyásolták az energiatartalomra vonatkozó információk. Egyelőre nem állnak rendelkezésre meggyőző bizonyítékok az étlapon szereplő tápanyag-összetétel hasznosságára. ${ }^{20} \mathrm{Az}$ írásos tájékoztatás helyett ugyanakkor a jelek és jelképek sokkal hatásosabbnak bizonyultak az egészséges étkezés előmozdításában.

A fogyasztó egészséges választását támogatná, ha az élelmiszergyártók, forgalmazók és a vendéglátók könnyebben értelmezhető jeleket, jelképeket alkalmaznának. Például a csomagolt termékek címkézésére többféle gyakorlat említhető. A zöld kulcslyukkal jelzett élelmiszerek megfelelnek annak az elvnek, hogy bizonyos élelmiszerekből többet, bizonyosakból kevesebbet egészséges fogyasztani [2. ábra; A]. Az élelmiszerek fő tápanyagaira vonatkozó mennyiség, a napi ajánlott mennyiségben mért arány mellett a közlekedési lámpák színjelzéseinek használata illetve csillagokkal osztályzása is használatos (2. ábra; B és C). A vásárlás közbeni gyors informálást feltehetően jobban szolgálja a csak színeket alkalmazó besorolás (2. ábra; D).

\section{2. ábra: Különböző élelmiszer-címkézési formák}

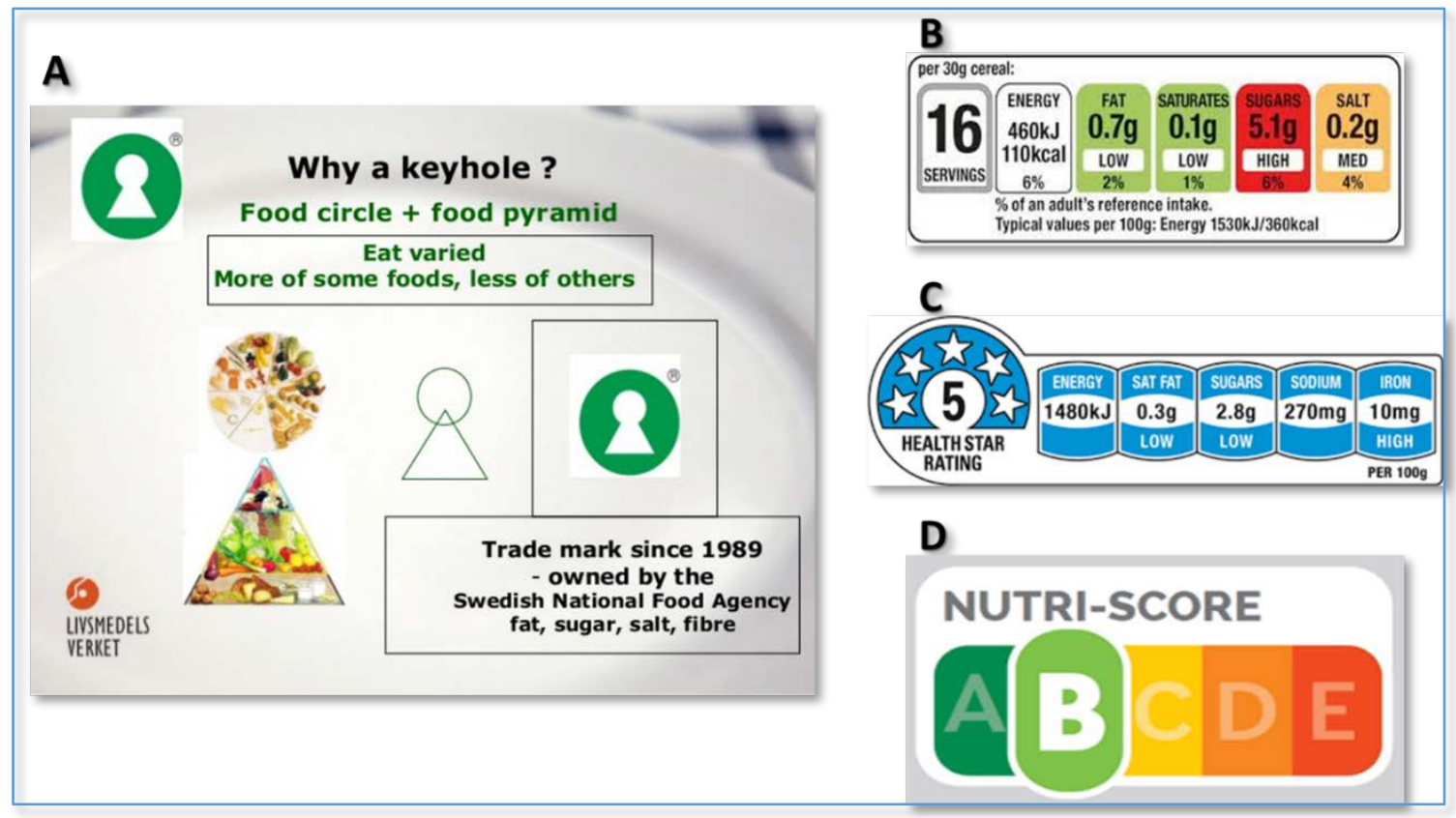

A tájékoztatás egyszerűsége feltétele az egészséges választás hatásos befolyásolásának. Így az energiaegységet jelölő csokoládészelet, sütemény vagy esetleg piros felkiáltójel egyértelmű üzenet lehet például a határértékhez közeli mennyiségben jelen lévő transzzsírsavra, sóra. (A New York Cityben müködő étteremláncok számára például már most kötelező figyelmeztető jelet tenni a 2,3 g sótartalmat meghaladó ételek mellé.)

Az egészséges választást befolyásoló információs környezet legfontosabb tényezője a média. A napilapok, a folyóiratok és a televíziós műsorok kiemelt szerepet játszanak az egészséggel kapcsolatos tudás és motiválás szempontjából. A médiamunkás 
tájékozottsága azonban alapvetően meghatározza a lakosságnak az egészséges életmóddal kapcsolatos ismereteit és motiváltságát is. Emiatt a népegészségügyi rendszernek az elhízásra vonatkozó, hiteles információkat összefoglaló sajtóanyagok közreadása mellett rendszeres találkozókat lenne érdemes szerveznie a médiamunkások tematikus felkészítésére.

Az információs környezetet - és természetesen a tanulók fizikai-szellemi környezetét is - meghatározó másik tényező az oktatási szektor. A köznevelési és a felsőfokú oktatási intézmények állami fenntartása kiváló lehetőséget kínál közvetlen beavatkozásra, hiszen a központi irányítással, finanszírozással viszonylag hatékonyan alakítható ki az elhízás megelőzését és visszaszorítását előmozdító környezet. Ez részben az egészséges táplálkozásra és a testmozgásra vonatkozó ismeretek és készségek fejlesztésével érhető el, megfelelő tananyagok és nevelési programok révén, részben az egészséges ételeket biztosító közétkeztetéssel, részben a mindennapi testnevelést támogató infrastruktúrával, összességében pedig a motiváló intézményi kultúra kialakításával hozható létre. ${ }^{21,22}$

Az előzőekben már említett okok miatt a bölcsődei, óvodai és iskolai étkeztetés kulcsszerepet játszik a hazai étkezési kultúra fejlesztésében. Az otthonról hozott, rossz étel- és italfogyasztási szokások megváltoztatásához - amint azt korábban is hangsúlyoztuk - nem elég új ismereteket átadni, hanem a meggyőzés (motiváció) és az új fogyasztási szokásokat támogató környezet is elengedhetetlen. A gyermekek étkezési kultúrájának kedvező irányú változtatásához tehát a bölcsődében, az óvodában és az iskolában az egészséges ételeken ${ }^{x i}$ túl az ételek kulturált elfogyasztásához szükséges környezetet ${ }^{\text {xii }}$ - beleértve a kellemes érzést nyújtó helyiséget, a kényelmes bútorzatot, az ízléses és higiénikus edényeket, evőeszközkészletet, a felszolgálás módját - és nem utolsó sorban, elegendő időt is kell biztosítani.

Az elhízás megelőzését és a lefogyást támogató környezet természetesen magába foglalja az egészséges életmódhoz szükséges termékek, szolgáltatások hozzáférhetőségét is. Ez alatt legtöbbször az elérhetőséget, a rendelkezésre állást, illetve a megfizethetőséget értik. Az elhízás visszaszorításának szempontjából kétségkívül támogató környezet az, ahol a lakóhely közelében olcsó és egészséges élelmiszereket árulnak, továbbá ahol ingyen vagy csupán jelképes összegért többféle sportolási lehetőség vehető igénybe. ${ }^{\text {xiii }} \mathrm{A}$ központi vagy helyi adópolitika például jelentősen képes befolyásolni az egészségbarát termékek hozzáférhetőségét ${ }^{\mathrm{xiv}}$, de az 1. ábrán a hozzáférést befolyásoló számos kormányzati intézkedés is megfigyelhető. Az egészségkockázatot jelentő élelmiszerekhez való hozzáférés korlátozására a csomagolt vagy felszolgált adag méretének szabályozása is megoldás lehet. Az édességipari cégek például - reagálva (kihasználva?) az egészségkultúra változására, illetve a hatóságok „ösztökélésére" (értsd: adóemelés) - időről időre csökkentik a csokoládészeletek méretét, miközben az árát változatlanul hagyják. Az adagok korlátozásának egy másik példája New York City Egészségügyi Bizottságának 2012-es döntése, melyben a gyorséttermekben árult cukros üdítők poharának űrtartalmát fél literben maximalizálta.. ${ }^{x} \mathrm{~A}$ nagy élelmiszeripari cégek azonban bírósági úton elérték, hogy a város 2014-ben visszavonja ezt a jogszabályt. Az előző példák arról tanúskodnak, hogy a nagy, globális vállalatok gazdasági érdekeiket követve akadályozhatják az egészséget védő szabályozást, de akár önként is hozhatnak egészségbarát döntéseket. Így talán a nem túl távoli jövőben a felszolgált adagok - az energiabevitel csökkentése érdekében - jóval kisebbek lesznek, és a mai átlagos adagokhoz szokott vendégek felár megfizetésével juthatnak csak „extra nagy" porcióhoz.

\footnotetext{
×i Ezt a célt szolgálja a közétkeztetést szabályozó 37/2014. EMMI rendelet, illetve az iskolabüfék, étel-, italautomaták kínálatát szabályozó, a nevelésioktatási intézmények működéséről és a köznevelési intézmények névhasználatáról szóló 20/1012. (VIII. 31.) EMMI rendelet 129.§ és 130.§-a. Ennek megfelelően a nevelési-oktatási intézményben, valamint a nevelési-oktatási intézményen kívül a gyermekek, tanulók részére szervezett rendezvényeken a népegészségügyi termékadóról szóló 2011. évi CIII. törvény hatálya alá tartozó termékek nem árusíthatók.

xii Ilyen fejlesztésekre lehet pályázni a Mintamenza kezdeményezés keretében: http://www.mnhsz.com/mintamenza/1-milliard-forint-palyazati-forrasa-gyermeketkeztetes-fejlesztesere (Elérve: 2017. 11. 14.)

xiii A két életmódtényező össze is kapcsolható: sportlétesítményekben, sportrendezvényeken egészséges étel-ital kínálat, mint például az Európa Egészséges Stadionok Hálózata; http://healthystadia.eu/sugary-drinks-awareness/ (Elérve: 2017. 11. 22.)

xiv Ilyen célt szolgál például a 2011. évi CIII. törvény a népegészségügyi termékadóról.

xv Összehasonlításképpen a magyar mozikban a legkisebb üdítőitalos pohár fél liter, és ha valaki ennél többre vágyik, akkor a film végéig akár 1 literes pohárban megvásárolt üdítő mellett 4 liternyi pattogatott kukoricát is elnassolhat.
} 


\section{KOMPLEX BEAVATKOZÁSOK SZÜKSÉGESSÉGE}

A fentiekből következően több szektorra kiterjedő, összehangolt intézkedésekre, beavatkozásokra van szükség ahhoz, hogy hazánkban sikeresen lehessen csökkenteni az elhízottak arányát. A viselkedésváltozáshoz vezető, igazoltan hatékony beavatkozási irányokat és szakpolitikákat a Michie és munkatársai által kifejlesztett "viselkedésváltoztatás kereke" modell foglalja össze ${ }^{23,24}$, és a modell gyakorlati alkalmazásához a szerzők beavatkozástervező eszközt is kifejlesztettek. ${ }^{25}$

Elméleti megfontolások és gyakorlati tapasztalatok igazolják, hogy a beavatkozások eredményessége növekszik, ha azokat egyaránt a magas kockázatú csoportokra célozva és a populáció szintjén is megvalósítják. ${ }^{26}$ Ezért lenne szükség a már elhízottak lefogyását előmozdító, ugyanakkor a teljes lakosságra is irányuló elhízásmegelőzést támogató programokra. A hazai "elhízásjárvány” megállítása - a megoldandó probléma összetettségéből eredően csakis az ilyen, több célcsoportot érintő, országos és helyi szintű, sok szereplő által megvalósított, a megváltoztatni kívánt viselkedés társadalmi beágyazottságát figyelembe vevő, komplex beavatkozásoktól várható. ${ }^{27,28}$
Az egészségmagatartás társadalmi beágyazottságának felismerése a népegészségügy 5 . hullámáig, az egészségkultúrára fókuszáló megközelítéshez vezetett. ${ }^{29}$ Mára ez a szemlélet a népegészségügyben olyannyira megkerülhetetlenné vált, hogy az Egészségügyi Világszervezet 2017-ben tanulmányt tett közzé az egészségkultúra kialakítását célzó szakpolitika támogatására. ${ }^{30} \mathrm{Az}$ elhízás visszaszorítását célzó programok kidolgozásához feltétlenül figyelembe kell venni ennek a tanulmánynak a táplálkozásra és a testmozgásra ${ }^{31}$, valamint az egészséges életmódot támogató környezetre vonatkozó fejezeteit. ${ }^{32}$

A javasolt három cél - azaz a tudásbővítés, a motiválás, és a támogató környezet kialakítása - egyidejű eléréséhez javasolt intézkedések megtervezése és megvalósítása komoly kihívás a szakpolitika számára. E feladat teljesítését célszerű a „szakpolitika, rendszer, környezet" megközelítés figyelembevételével előkészíteni. ${ }^{33}$ A szakirodalom alapján kifejlesztett modell szerint három területen - vagyis a probléma feltérképezése, azonosítása, a megoldásához szükséges szakpolitika kidolgozása, valamint a politikai környezet támogatásának elnyerése területén - szükséges sikeres akciókat megvalósítani. [3. ábra]

3. ábra: A „szakpolitika, rendszer, környezet” megközelités modellje

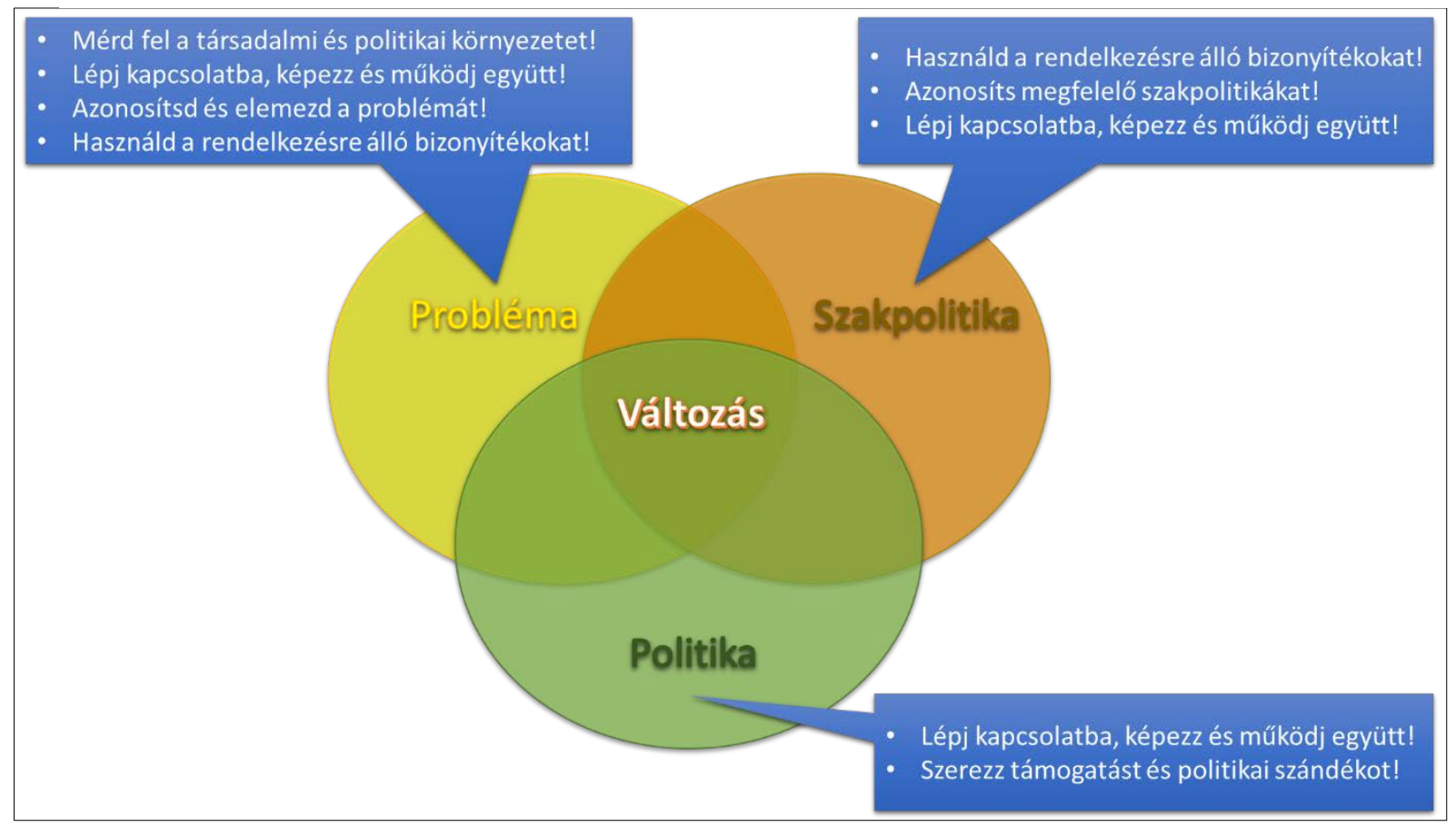

Forrás: Vitrai J. $2017^{33}$ 
Mind az elméleti megfontolások, mind a nemzetközi tapasztalatok alapján levonható a következtetés: az elhízás visszaszorítását célzó hazai stratégia sikerének előfeltétele, hogy az egészségügyi szakpolitika koordinációjával valamennyi szektor konstruktívan részt vegyen a megvalósításban országosan, regionálisan és helyi szinten egyaránt. A stratégia megvalósítása tehát nemcsak a "felülről lefelé”, hanem a „lentről felfelé” megközelítés alkalmazását is igényli, amint azt az utóbbi években megjelent idevágó kutatások is igazolják. ${ }^{34}$ Ehhez leginkább alkalmas a rendszerszintű gondolkodás és cselekvés, azaz egyidejüleg szükséges elemezni és összeegyeztetni az országos, a térségi és a helyi szintek érdekeit, lehetőségeit. ${ }^{35}$

A megvalósítás tervezésekor továbbá ügyelni kell arra is, hogy a beavatkozások ne növeljék tovább a már ma is jelentős hazai egészségegyenlőtlenségeket. ${ }^{36} \mathrm{Az}$ egyenlőtlenségek alapvető társadalmi okairól szóló elmélet alapján olyan elhízásellenes szakpolitika lehet sikeres, amely az egyéni felelős- ségre alapozó felfogás helyett, az egyén környezetét és életkörülményeit befolyásolni képes társadalmi szereplők tevékenységére hat. ${ }^{37}$

\section{ZÁRÓGONDOLATOK}

A társadalomban alapvető attitűdváltásra van szükség ahhoz, hogy kevesebb túlsúlyos vagy elhízott nézzen szembe az elkerülhetetlen egészségkárosodással Magyarországon. El kell elérni, hogy a lakosság általában ne megértően és elfogadóan tekintsen az elhízásra, hanem komoly egészségkockázatnak lássa, mint ahogyan a dohányzás esetében történt az elmúlt évtizedben.

Az elhízás elleni küzdelem során - sportnyelven szólva - a szakpolitikának edzőként korszerűbb, erőteljesebb játékra kell ösztönöznie, és a csapat számára új taktikát, egészpályás letámadást kell választania.

\section{HIVATKOZÁSOK}

\footnotetext{
${ }^{1}$ Health Effects of Overweight and Obesity in 195 Countries over 25 Years. N Engl J Med. 2017;377:13-27. doi: http://dx.doi.org/10.1056/NEJMoa1614362.

2 Európai lakossági egészségfelmérés, 2014. Központi Statisztikai Hivatal, Statisztikai Tükör, 2015;29:7.

${ }^{3}$ Erdei G et al. Országos Táplálkozás és Tápláltsági Állapot Vizsgálat 2014 - I. A magyar felnőtt lakosság tápláltsági állapota. Orvosi Hetilap. 2017;158(14):533-40. https://doi.org/10.1556/650.2017.30700

${ }^{4}$ Health at a Glance 2017. OECD, 2017. http://dx.doi.org/10.1787/health glance-2017-en

${ }^{5}$ MÉRTÉK munkacsoport. A magyar egészségügyi rendszer teljesítményértékelése 2013-15. Állami Egészségügyi Ellátó Központ, Budapest, 2016

${ }^{6}$ Schneider S, Diehl K, Görig T, et al. BMC Public Health (2017) 17:760; doi: http://dx.doi.org/10.1186/s12889-017-4790$\underline{x}$.

${ }^{7}$ Series from the Lancet journals: Obesity 2015. http://www.thelancet.com/series/obesity-2015 (Elérve: 2017.10.18.)

${ }^{8}$ Csizmadia $P$, Varsányi $P$, Ferencz $M$, et al. Az egészségbarát viselkedést befolyásoló hatásháló. Egészségfejlesztés. 2014;5-6:10-3.

${ }^{9}$ Vitrai J, Kimmel Zs. Mennyire változtatható jogszabályokkal az egészségmagatartás? Mitől függ és hogyan változtatható az egészségmagatartás? I. rész. Egészségtudomány. 2015;3:57-70.

${ }^{10}$ Grist R, Porter J, Stallard P. Mental Health Mobile Apps for Preadolescents and Adolescents: A Systematic Review. Journal of Medical Internet Research. 2017;19(5):e176. doi: http://dx.doi.org/10.2196/jmir.7332.

${ }^{11}$ Dute DJ, Bemelmans WJE, Breda J. Using Mobile Apps to Promote a Healthy Lifestyle Among Adolescents and Students: A Review of the Theoretical Basis and Lessons Learned. JMIR mHealth and uHealth. 2016;4(2):e39. doi: http://dx.doi.org/10.2196/mhealth.3559.

12 Stephenson A, McDonough SM, Murphy MH, et al. Using computer, mobile and wearable technology enhanced interventions to reduce sedentary behaviour: a systematic review and meta-analysis. Int J Behavioral Nutrition and Physical Activity. 2017;14:105. doi: http://dx.doi.org/10.1186/s12966-017-0561-4.

${ }^{13}$ Schoeppe S, Alley S, Van LW, et al. Efficacy of interventions that use apps to improve diet, physical activity and sedentary behaviour: a systematic review. Int J Behavioral Nutrition and Physical Activity. 2016;13:127. doi: http://dx.doi.org/10.1186/s12966-016-0454-y.
} 
${ }^{14}$ Davis KC Patel D, Shafer P, et al. Association Between Media Doses of the Tips From Former Smokers Campaign and Cessation Behaviors and Intentions to Quit Among Cigarette Smokers, 2012-2015. Heal Educ Behav 2017; doi: http://dx.doi.org/10.1177/1090198117709316.

${ }^{15}$ Kaposvári Cs, Vitrai J. Hogyan fejlesszük egy ország egészségkultúráját? A RAND Corporation jelentésének ismertetése. Egészségfejlesztés. 2017;58(3):34-41. doi: http://dx.doi.org/10.24365/ef.v58i3.179.

${ }^{16}$ Galbraith-Emami S, Lobstein T. The impact of initiatives to limit the advertising of food and beverage products to children: a systematic review. Obes Rev. 2013;14: 960-74. doi: http://dx.doi.org/10.1111/obr.12060.

${ }^{17}$ Chambers SA Freeman R, Anderson AS, et al. Reducing the volume, exposure and negative impacts of advertising for foods high in fat, sugar and salt to children: A systematic review of the evidence from statutory and self-regulatory actions and educational measures. Preventive Medicine. 2015;75:32-43. https://doi.org/10.1016/j.ypmed.2015.02.011. ${ }^{18}$ Csizmadia P. Az épített környezet hatása az egészségmagatartásra workshop. Egészségfejlesztés. 2016;57(2):85-8. doi:http://dx.doi.org/10.24365/ef.v57i2.25.

${ }^{19}$ Csizmadia P, Szűcs E. Szempontok az egészséges életmódot támogató épített környezet kialakításához. Egészségfejlesztés. 2016;57(4):38-46. doi: http://dx.doi.org/10.24365/ef.v57i4.86.

${ }^{20}$ Fernandes AC, Oliveira RC, Proença RP, et al. Influence of menu labeling on food choices in real-life settings: a systematic review. Nutrition Reviews. 2016;74(8):534-48; https://doi.org/10.1093/nutrit/nuw013.

${ }^{21}$ Járomi É, Szilágyi K, Vitrai J. Egészséges életmóddal kapcsolatos kutatások a hazai iskolákban. Egészségfejlesztés. 2016;57(1):2-40. doi: http://dx.doi.org/10.24365/ef.v57i1.24.

22 Járomi É, Vitrai J. Az iskolai egészségfejlesztés hazai és nemzetközi szemléletének bemutatatása. Egészségfejlesztés. 2017;58(1):36-48. doi: http://dx.doi.org/10.24365/ef.v58i1.145.

${ }^{23}$ Michie S, van Stralen MM, West R. The behaviour change wheel: A new method for characterising and designing behaviour change interventions. Implementation Science. 2011;6:42. doi: http://dx.doi.org/10.1186/1748-5908-6-42.

${ }^{24}$ Kimmel Zs, Vitrai J. Mennyire változtatható jogszabályokkal az egészségmagatartás? Elegendőek-e a szabályozások az egészségmagatartás megváltoztatásához? II. rész. Egészségtudomány. 2015.3:71-8.

25 Járomi É, Szűcs E, Vitrai J. Egészségstílusokhoz illesztett, viselkedésváltozást célzó beavatkozások tervezése. Egészségfejlesztés. 2016; 57(2):34-50. doi: http://dx.doi.org/10.24365/ef.v57i2.47.

${ }^{26}$ Járomi É, Kimmel Zs. Komplex egészségfejlesztési beavatkozások lehetséges prevenciós megközelítései. Egészségfejlesztés. 2017;58(2):20-29. doi:http://dx.doi.org/10.24365/ef.v58i2.164.

${ }^{27}$ Schneider S, Diehl K, Görig T, et al. Contextual influences on physical activity and eating habits - options for action on the community level. BMC Public Health. 2017;17:760. doi: http://dx.doi.org/10.1186/s12889-017-4790-x.

${ }^{28}$ Pfadenhauer LM, Gerhardus A, Mozygemba K, et al. Making sense of complexity in context and implementation: the Context and Implementation of Complex Interventions (CICl) framework. Implementation Science. 2017;12:21. doi: http://dx.doi.org/10.1186/s13012-017-0552-5.

${ }^{29}$ Davies SC, Winpenny E, Ball S, et al. For debate: a new wave in public health improvement. Lancet. 2014;6736:1-7. doi: http://dx.doi.org/10.1016/S0140-6736(13)62341-7.

30 Vitrai J. Hogyan befolyásolja a kultúra az egészséget és a jóllétet? I. rész: Az egészség kulturális beágyazottsága. Egészségfejlesztés. 2017;58(2):38-41. doi:http://dx.doi.org/10.24365/ef.v58i2.158.

${ }^{31}$ Nagy B. Hogyan befolyásolja a kultúra az egészséget? II. rész: Táplálkozás, kultúra és egészség? Egészségfejlesztés. 2017;58(2):42-46. doi:http://dx.doi.org/10.24365/ef.v58i2.159.

${ }^{32}$ Csizmadia P. Hogyan befolyásolja a kultúra az egészséget és a jóllétet? III. rész: Környezet, kultúra és egészség. Egészségfejlesztés. 2017;58(2):47-50. doi: http://dx.doi.org/10.24365/ef.v58i2.160.

${ }^{33}$ Vitrai J. 'Szakpolitika, rendszer, környezet' megközelítés az elhízás megelőzésében: elméleti keretek helyi és állami beavatkozásokhoz. Egészségfejlesztés. 2017;58(3):57-58. doi: http://dx.doi.org/10.24365/ef.v58i3.177.

${ }^{34}$ Huang TTK, Cawley JH, Ashe M, et al. Mobilisation of public support for policy actions to prevent obesity. Lancet. 2015;385(9985):2422-31. doi: http://dx.doi.org/10.1016/S0140-6736(14)61743-8.

35 Johnston LM, Matteson CL, Finegood DT. Systems Science and Obesity Policy: A Novel Framework for Analyzing and Rethinking Population-Level Planning. Am J Public Health. 2014;104(7):1270-8. doi:

http://dx.doi.org/10.2105/AJPH.2014.301884.

${ }^{36}$ Orosz É, Kollányi Zs. Egészségi állapot, egészség-egyenlőtlenségek nemzetközi összehasonlításban. In: Kolossy T, Tóth István Gy. (szerk.)Társadalmi Riport 2016. TÁRKI, 2016.

${ }^{37}$ Csizmadia P. Az egyenlőtlenségek alapvető társadalmi okai és az elmélet alkalmazási lehetőségei az egészségügyi szakpolitikákban. Egészségfejlesztés. 2017;58(2):17-9. doi: http://dx.doi.org/10.24365/ef.v58i2.168. 